\title{
Distinctive life traits and distribution along environmental gradients of dominant and subordinate Mediterranean ant species
}

\author{
Xavier Arnan · Xim Cerdá · Javier Retana
}

\begin{abstract}
For most animal and plant species, life traits strongly affect their species-specific role, function or position within ecological communities. Previous studies on ant communities have mostly focused on the role of dominant species and the outcome of interspecific interactions. However, life traits of ant species have seldom been considered within a community framework. This study (1) analyses life traits related to ecological and behavioural characteristics of dominant and subordinate ant species from 13 sites distributed throughout the Iberian Peninsula, (2) determines how similar the ant species are within each of the two levels of the dominance hierarchy, and (3) establishes the distribution patterns of these different groups of species along environmental gradients. Our results showed that the differences between dominants and subordinates fall into two main categories: resource exploitation and thermal tolerance. Dominant species have more populated colonies and defend food resources more fiercely than subordinates, but they display low tolerance to high temperatures. We have identified different assemblages of species included within each of these two levels
\end{abstract}

Communicated by Phil Lester.

Electronic supplementary material The online version of this article (doi:10.1007/s00442-012-2315-y) contains supplementary material, which is available to authorized users.

X. Arnan (\&) · J. Retana

Unitat d'Ecologia i CREAF, Facultat de Biociències, Universitat Autònoma de Barcelona, 08193, Bellaterra (Barcelona), Spain e-mail: x.arnan@creaf.uab.es

X. Cerdá

Estación Biológica de Doñana, Consejo Superior de Investigaciones Científicas, Avda. Américo Vespucio, 41092 Sevilla, Spain in the dominance hierarchy. The distribution of these assemblages varied along the environmental gradient, shifting from dominant Dolichoderinae and cryptic species in moist areas, to dominant Myrmicinae and hot climate specialists mainly in open and hot sites. We have been able to identify a set of life traits of the most common Iberian ant species that has enabled us to characterise groups of dominant and subordinate species. Although certain common features within the groups of both dominants and subordinates always emerge, other different features allow for differentiating subgroups within each of these groups. These different traits allow the different subgroups coping with particular conditions across environmental gradients.

Keywords Dominance hierarchy · Formicidae · Species similarity $\cdot$ Temperature $\cdot$ Vegetation cover

\section{Introduction}

The analysis of natural communities can be conducted using different approaches. At one extreme, many authors have recognised certain similarities in pattern and function at the community level, and thus appreciate common denominators of structure or organisation (Putman 1994; Melville et al. 2006). At the other extreme, the search for patterns may also be achieved by focusing attention on the life traits and interactions of individual species. With such information, one can attempt to build up a picture of the community and its operation as a mix of interacting component parts. Species differ from one another in their response to environmental conditions and in their sensitivities to changes in the complex of other species and resources with which they may interact (Wiens et al. 1986). These differences have frequently been related to the life 
traits of species that buffer them against adverse conditions of the biotic or physical environment (Chesson and Huntly 1988). Theoretical studies have shown that specific life traits can play a considerable role in the ecology and diversity of natural communities (Chesson and Huntly 1988; Sevenster and Van Alphen 1993). Life traits of species, which include both morphological and physiological properties affecting tolerance or diet breadth and ecological and behavioural characteristics determining habitat or resource selection (Futuyma and Moreno 1988; Thygesen et al. 2005), may provide information about the factors controlling the presence and absence of particular species and, thus, the composition of communities. Of all the species that have the appropriate physiology to cope with prevailing environmental conditions, only one small subset is represented within any actual community matrix (Putman 1994). The presence of certain species and their relative abundance depends on the biotic relationships among them, and especially on competitive interactions (Pisarski and Vepsälainen 1989; Putman 1994; Parr 2008).

Ant species have been grouped into different levels of interacting species within hierarchies (Savolainen and Vepsäläinen 1988; Pisarski and Vepsäläinen 1989; Cerdá et al. 1997, 1998a; Bestelmeyer 2000; Arnan et al. 2011). Dominance hierarchies among ant species are a worldwide phenomenon (Hölldobler and Wilson 1990) and are based mainly on behavioural differences in communication and aggressiveness (Savolainen et al. 1989). In these hierarchies, ant species fall into two main categories: species that are highly aggressive and behaviourally dominant and those that are less aggressive and subordinate. A dominant species is one that is capable of exerting a strong influence over other species: an ant species is dominant if it initiates attack and by its mere presence elicits avoidance behaviour in an encounter with another species (Cerdá et al. 1997). The aggressive, dominant species use interference to behaviourally exclude subordinates from resources (Savolainen and Vepsäläinen 1988; Pisarski and Vepsäläinen 1989; Cerdá et al. 1998a). Dominant species belong to completely different taxonomic (and also ecological) groups (Hölldobler and Wilson 1990). In Australia, the behaviourally dominant taxa that reach their maximum abundance in hot and open environments are exclusively members of the subfamily Dolichoderinae (Andersen 1995; Gibb and Hochuli 2004). In cold-temperate forests, the dominant species of the genus Formica are the major structuring force of ant species assemblages (Savolainen and Vepsäläinen 1988; Deslippe and Savolainen 1995), while in other areas, where there are no species with this high degree of dominance (i.e., highly aggressive and abundant), some species (also named dominants) exert strong competitive interactions and regulate the structure and composition of the community as well (Cerdá et al.
1997). There are also major differences among subordinate species. Subordinate species may be divided into two groups: those that avoid competition with dominants by reducing the spatial or temporal overlap (Human and Gordon 1996; Holway 1998) and those that coexist spatially and/or temporally with dominants, but limit their interactions with these aggressive species as far as possible (Human et al. 1998), i.e. cryptic species. In each case, the differences within each group usually imply different life traits. For instance, cryptic species would be expected to be smaller and/or slower than dominants. Then, dominants would not consider cryptic species serious competitors and so let them be, while this would not necessarily be so in the case of the former group of subordinates. A key point is to identify the life traits characterising the groups of dominant and subordinate species found in each biogeographical area and to relate them to community composition.

In the Mediterranean region, as well as in other arid and semi-arid zones, the main phenomenon causing stress is climate, because there is severe drought in summer, when mean temperatures are also highest (Orshan 1983). Ants can cope with these stresses of the Mediterranean climate by either enduring or avoiding them. Endurance generally involves physiological adaptations (e.g. evaporative cooling, tolerance of water deprivation). More often, species simply avoid extreme conditions through adjustments in behavioural or ecological features of life histories (Cerdá and Retana 2000). In these communities, a wide thermal range increases species diversity, because different species are favoured by different sorts of thermal conditions, so that temporal changes in foraging abundance of species (Cerdá et al. 1997; Cros et al. 1997) lead to an increase in the number of abundant species and, consequently, species diversity (Cerdá et al. 1997; Retana and Cerdá 2000). It has already been described how these temporal patterns can, at least partially, be related to the position of species in the dominance hierarchy, with dominants behaving mainly as heat-intolerant species that forage at low temperatures, and subordinates mainly behaving as heat-tolerant species that forage at high temperatures (Cerdá et al. 1997, 1998b, c). Over the last two decades, Mediterranean ant communities from the Iberian Peninsula have been extensively studied (Cerdá et al. 1997, 1998a, b, c; Cros et al. 1997; Retana and Cerdá 2000; Arnan et al. 2006, 2007; Pekas et al. 2011). Consequently, there is a relatively large amount of information on the ecological and behavioural characteristics of dominants and subordinates present in these communities. Specific objectives are (1) to examine communities for life traits that consistently describe dominant and subordinate species; (2) to analyse to what extent the ant species at the same level in the dominance hierarchy (i.e. subordinates and dominants) differ, and consequently to determine if different subgroups of dominant and subordinate species 
can be identified regarding this set of life traits; and (3) to determine to what extent the distribution patterns of the different groups of species defined in the two first objectives can be described from environmental gradients.

\section{Materials and methods}

\section{Study sites and species}

The study was performed in 13 sites distributed from northeastern to southern Spain, which encompass a considerable variety of vegetation types (five open grasslands and eight shrublands and forests) (Table 1). Study sites were described in a previous paper (see Retana and Cerdá 2000). Tree cover in the sites ranged from 0 to $90 \%$ and understory cover from 5 to $60 \%$ (Table 1). Ant abundance in each site was determined by pitfall traps. The different communities were sampled in different years from 1983 to 2000. Similar trap numbers were used at each site: four or five series of five traps each (with 5-m spacing between traps and non-fixed spacing between series: minimum and maximum distances between trap series were 10 and $25 \mathrm{~m}$, respectively) were laid over the study area. Pitfall traps were 6-cm-diameter, 7-cm-deep plastic vials partially filled with water, ethanol and soap. Traps were laid during two contrasting periods within the usual activity period of most Mediterranean ant species (Cros et al. 1997). Thus, traps were operated for 4-6 days during mid-May (spring period) and repeated in mid-July (summer period). A total number of 6-15 ant species were identified in the different sites. Thirty ant species, which were the most common species in the different sites, were considered in this study (see Table S1). They accounted for 96.1-100 \% of the total ant fauna collected in pitfall traps in each site.

Identification of the role of ant species in the dominance hierarchy

To determine the role of each species in the dominance hierarchy, we used baits. In each site, excepting sites 7-10, four-five series of five-six baits each were laid randomly over the entire study area (with 5-m spacing between two adjacent baits and also between series) for a total of 4-6 sampling days of $24 \mathrm{~h}$ each in spring, and repeated in summer. Baits were plastic discs, each of them with a different large food reward (honey, bacon, sausage, cheese, biscuit and, exceptionally, ham) attractive to ants that tried to cover a wide range of potential types of food for ants. Each bait only had one of these food items, and all of them were represented within each set. Bait sampling was conducted on the same days as pitfall traps. Each hour of every 24-h sampling period, the number of ants from the different species feeding at each bait and the interactions among species were noted. We distinguished three different types of interspecific interactions: (1) expulsion of one species by another; (2) escape of one species from the bait caused by the attack of another; and (3) coexistence of two or more species.

Behavioural dominance of ant species was determined by observing interspecific interactions at baits. For each species, we calculated the dominance index (sensu Fellers
Table 1 Geographical location and main characteristics of vegetation and ant community structure in the 13 sites considered in this study (ordered from north-eastern to south-western Spain)

Vegetation type and cover (\%), number of ant species collected in pitfall traps and percentage of workers captured that correspond to species considered in this study are indicated

\begin{tabular}{|c|c|c|c|c|c|c|}
\hline Site & Geographical location & Vegetation type & $\begin{array}{l}\text { Tree } \\
\text { cover } \\
(\%)\end{array}$ & $\begin{array}{l}\text { Understory } \\
\text { cover (\%) }\end{array}$ & $\begin{array}{l}\text { No. of } \\
\text { ant } \\
\text { species }\end{array}$ & $\begin{array}{l}\% \text { ant } \\
\text { fauna } \\
\text { in this } \\
\text { study }\end{array}$ \\
\hline 1 & Portbou (Girona) & Grassland & 0 & 20 & 8 & 99.4 \\
\hline 2 & Portbou (Girona) & Shrubland & 0 & 40 & 10 & 99.6 \\
\hline 3 & Portbou (Girona) & Open mixed forest & 40 & 40 & 8 & 98.3 \\
\hline 4 & Canet de Mar (Barcelona) & Grassland & 0 & 25 & 12 & 99.8 \\
\hline 5 & Canet de Mar (Barcelona) & $\begin{array}{l}\text { Open holm oak } \\
\text { forest }\end{array}$ & 40 & 50 & 15 & 98.3 \\
\hline 6 & Canet de Mar (Barcelona) & Open pine forest & 60 & 20 & 15 & 98.7 \\
\hline 7 & Serra de l’Obac (Barcelona) & Forest gap & 60 & 30 & 15 & 99.6 \\
\hline 8 & Serra de l’Obac (Barcelona) & $\begin{array}{l}\text { Open holm oak } \\
\text { forest }\end{array}$ & 70 & 40 & 11 & 96.1 \\
\hline 9 & Serra de l’Obac (Barcelona) & Holm oak forest & 90 & 40 & 13 & 96.5 \\
\hline 10 & Bellaterra (Barcelona) & Grassland & 0 & 25 & 13 & 99.9 \\
\hline 11 & $\begin{array}{l}\text { Serra de Collserola } \\
\text { (Barcelona) }\end{array}$ & Shrubland & 0 & 60 & 9 & 100 \\
\hline 12 & Sierra Sur (Jaén) & Grassland & 0 & 5 & 11 & 100 \\
\hline 13 & $\begin{array}{l}\text { Doñana National Park } \\
\text { (Huelva) }\end{array}$ & Grassland & 0 & 10 & 6 & 100 \\
\hline
\end{tabular}


1987 or Cerdá et al. 1997), which was the percent of encounters won (i.e. it drove away another species) in all of its interspecific encounters. Species were classified into one of two dominance groups: (1) dominants, which were at the top of the dominance hierarchy, and drove away the majority of ant species from food resources, and (2) subordinates, which were at the bottom of the hierarchy, and were forced to abandon the baits by dominants. Cut-off points for distinguishing dominants from subordinates were established in each community according to the criteria described in Retana and Cerdá (2000). Thus, dominant species were those that (1) had a dominance index greater than $50 \%$, or (2) had a dominance index which did not statistically differ (based on a $\mathrm{v}^{2}$ test) from that of species classified as dominants following the former criterion. The other species were subordinates. We used unpublished information provided by various colleagues (Sebastià Cros and Anna Alsina) to assign species from sites 7-10 to these categories. Species categorisation was highly coincident among the different study sites. Thus, species that occurred in several study sites were always classified as either dominant or subordinate regardless of site.

\section{Life traits of species}

Descriptions of ecological and biological features of ant species from the different groups (i.e. dominants and subordinates) were based on a tabulation of 14 life traits. The selection of traits was based on characteristics that are recognized as important in ant autoecology (Hölldobler and Wilson 1990; Lach et al. 2010), and considering the feasibility of achieving data. Information was obtained from personal data, from the literature (Cerdá and Retana 1997a, 2000; Cerdá et al. 1989, 1990, 1997, 1998a, b; Arnan et al. 2006) and from personal communications from different colleagues (Anna Alsina, Jordi Bosch, Soledad Carpintero, Valentín Cavia, Sebastià Cros, Xavier Espadaler and Alberto Tinaut). A discrete category was assigned for the following variables:

1. Worker polymorphism: 1, monomorphism (e.g. Linepithema humile); 2, low polymorphism (e.g. Tapinoma nigerrimum); 3, high polymorphism (e.g. Camponotus cruentatus).

2. Colony population: 1, hundreds of workers; 2, thousands of workers; 3 , tens of thousands of workers.

3. Number of queens per colony: 1 , only one queen (monogyny); 2, more than one queen (polygyny).

4. Number of nests per colony: 1, only one nest (monodomy); 2, more than one nest (polydomy).

5. Brood cycle: 1, larvae within the nests from March to September (foraging activity season); 2, larvae within the nests during the whole year (also in winter).
6. Diet (main food resource): 1, arthropod corpses (scavenger species); 2, nectar (nectar-eating species); 3 , seeds (granivorous species); 4, honeydew (aphidtender species).

7. Defence of resources: 1 , none (only defence of the nest); 2, defence of food or territory (foraging area).

8. Daily activity rhythm: 1 , strictly diurnal; 2 , diurnal in spring and continuous throughout the day or with a midday drop in summer; 3 , continuous in spring and nocturnal in summer; 4, always nocturnal.

9. Months of maximum activity: 5-10, from May to October. It corresponds to the month of highest frequency of ants at baits from studies where seasonal ant activity was assessed throughout the year (e.g. Cros et al. 1997).

Quantitative values were obtained for the other five variables:

10. Worker size. Total body length of fresh samples of 20-100 workers of each species was measured in the laboratory under a stereoscopic microscope, from tip of mandibles to tip of gaster, with the ant in an extended position.

11. Number of workers at baits. The mean number of workers of each species counted at baits was calculated considering the data from all baits of all hours of all sampling days where the species was present.

12. Critical thermal maximum (CTM). This variable represents the maximum physiological thermal limit of each species. It was measured at the laboratory by means of an electric Plactronic Selecta hot plate, with a $5-200{ }^{\circ} \mathrm{C}$ temperature range and $1{ }^{\circ} \mathrm{C}$ of accuracy. Twenty individuals of each species were exposed during $10 \mathrm{~min}$ to each temperature (from 20 to $60{ }^{\circ} \mathrm{C}$, depending on the thermal tolerance of each species). The CTM of each species was considered to be the temperature at which at least $50 \%$ of workers died or lost muscular coordination after $10 \mathrm{~min}$ of exposure. A more detailed description of the method is given in Cerdá et al. (1998b).

13. Maximal activity temperature (MAT). This variable represents the temperature at which the mean foraging activity value was greatest in field conditions; it is the optimal (or preferred) ground temperature of the species to forage. It was established by dividing the whole range of temperatures registered in the field into two- ${ }^{\circ} \mathrm{C}$ classes. The mean activity value of each species in each temperature class was computed by averaging ant abundance at baits every time that this temperature was reached throughout all sampling days. Ground surface temperatures were measured with glass-headed thermocouples and a Univolt DT830 multimeter. 
14. Difference between CTM and MAT temperatures (CTM-MAT). This variable is an estimate of how close (low values) or far (high values) from risk temperatures (i.e. CTM) is the maximum foraging temperature of the species (i.e. MAT).

Life traits were assumed to be species-specific without inter-site variability, and therefore samples for quantitative values were obtained from any of the study sites. Life trait values for all species are provided as a Supplementary Material (Table S1).

Data analysis

Examination of life traits that consistently describe dominant and subordinate species

Life traits of dominant and subordinate ant species were compared using non-parametric procedures. Differences in three cardinal variables (main food resource, month of maximum activity, daily activity rhythm) were tested with Chi-squared tests where counts were the different ant species. Differences in the other eleven continuous or ordinal variables were analysed by Mann-Whitney U tests.

Establishment of different groups of dominant and subordinate species according to these life traits

In order to know how similar the ant species were within each of the two levels of the dominance hierarchy, and whether or not different sets of species could be identified within each level, a matrix of inter-species similarities was drawn up from the original dataset. This matrix was then used to create a hierarchical dendrogram by clustering methods. A Proportional Similarity Index (PSI; modified from Colwell and Futuyma 1971) between each species pair was calculated considering all the life traits:

PSI $1 / 41-\mathrm{R}^{\circ} \mathrm{stP}_{\mathrm{ix}}-\mathrm{stP}_{\mathrm{iy}}{ }^{\circ}=\mathrm{n}$

where $\mathrm{stP}_{\mathrm{ix}}$ and $\mathrm{stP}_{\mathrm{iy}}$ were the standardised proportional values of life trait $\mathrm{i}$ of ant species $\mathrm{x}$ and ant species $\mathrm{y}$, respectively, and $\mathrm{n}$ is the number of life traits used for calculations. This correction is carried out for obtaining PSI values comprised between 0 (very different species) and 1 (very similar species). The standardisation of proportional values $\left(\mathrm{stP}_{\mathrm{ix}}\right)$ of traits was calculated as:

$\mathrm{stP}_{\mathrm{ix}} 1 / 4 \mathrm{P}_{\mathrm{ix}}=$ „ $\mathrm{P}_{\text {imax }}-\mathrm{P}_{\text {imin }} \mathrm{p}$

where $\mathrm{P}_{\mathrm{ix}}$ is the value of the trait $\mathrm{i}$ for the species $\mathrm{x}$, and $\left(\mathrm{P}_{\text {imax }}-\mathrm{P}_{\text {imin }}\right)$ is the range (difference between the maximum and minimum values) of the trait i for all species. In the case of qualitative variables with more than two cases that were not ordered (diet and daily activity rhythm), the similarity was 1 when the two species coincided for the same case, and 0 when they did not.

The grouping of ant species based on their life traits was carried out with the Cluster Analysis of Statistica (StatSoft 2001). An UPGMA (unweighted pair-group average method analysis) was performed from the similarity matrix. Once groups established, their statistical differences on those quantitative and ordinal life traits were tested by Kruskal-Wallis tests, where species were the replicates within each group. Post-hoc pairwise comparisons were conducted with the Tukey's post-hoc test.

To investigate the importance of phylogeny on the similarity of life traits of species, we related the matrix of similarities in life traits among species with a matrix of phylogenetic proximity of species. A working phylogeny of the 30 species was constructed based on Baroni-Urbani et al. (1992). The five Cataglyphis species and the four Messor species were ordered according to Tinaut (unpublished data). Since branch lengths in the ant tree were unknown, we assigned equal branch lengths to all the branches of the tree, a method that recent simulation work has shown to perform reasonably well (Purvis et al. 1994). The elements of the matrix of phylogenetic distances were the number of nodes that separated each species pair. This matrix was transformed into a similarity matrix. The relationship between two matrices was estimated by computing the Mantel test with the MANTEL program of the $\mathrm{R}$ package (Legendre and Vaudor 1991).

Distribution patterns of the different groups of species along environmental gradients

To examine the distribution patterns of the different groups of species (generated from the previous cluster analysis) along environmental gradients, we used canonical correspondence analysis (CCA) which generated a biplot of the relationships between the abundance of the different groups of dominant and subordinate species and site habitat variables (ter Braak and Smilauer 1998). The following environmental variables were considered in the CCA analysis: annual mean temperature, annual total precipitation, tree cover (\%) and understory cover (\%). The values of the first two variables were obtained from the Atlas Climático Digital de la Península Ibérica (Ninyerola et al. 2005), while the latter two were obtained from Retana and Cerdá (2000) and from unpublished information.

\section{Results}

A total of 10 dominant and 20 subordinate species were identified in the study sites. Nine (30\%) of these species were only found in the grassland sites, 5 (16.7\%) were 
only found in the shrubland/forest sites, while the remainder were found in both grassland and shrubland/ forest sites.

Examination of life traits that consistently describe dominant and subordinate species

Results shown in Table 2 indicate that there were significant differences between dominant and subordinate species in 7 out of 14 of these ecological and behavioural traits. Neither worker size nor polymorphism of the worker caste presented significant differences between the two groups. However, differences between dominants and subordinates were found in foraging strategy: dominant species had more workers at baits (mean \pm SD: $35.3 \pm 22.0$ and $9.9 \pm 10.0$ workers for dominant and subordinate species, respectively), and defended resources more fiercely than did subordinates. There were also differences in colony size, with dominants having more populated colonies than subordinates, but not in colony composition (number of queens or number of nests per colony). Dominants and subordinates differed in their diet: subordinates were predominantly scavenger and nectar-eating species (90\% of

Table 2 Statistical comparison of life traits between the dominant $(\mathrm{n}=10)$ and subordinate $(\mathrm{n}=20)$ ant species identified in the Mediterranean ant communities studied

\begin{tabular}{|c|c|c|}
\hline Life trait & Statistical test & Significance \\
\hline Worker size (mm) & $\begin{array}{l}\text { Mann-Whitney } \\
\text { U test }\end{array}$ & 0.947 \\
\hline Polymorphism & $\begin{array}{l}\text { Mann-Whitney } \\
\text { U test }\end{array}$ & 0.172 \\
\hline Defence of resources & $\begin{array}{l}\text { Mann-Whitney } \\
\text { U test }\end{array}$ & $<0.001$ \\
\hline Number of workers per bait & $\begin{array}{l}\text { Mann-Whitney } \\
\text { U test }\end{array}$ & 0.001 \\
\hline Colony population & $\begin{array}{l}\text { Mann-Whitney } \\
\text { U test }\end{array}$ & $<0.001$ \\
\hline Brood cycle index & $\begin{array}{l}\text { Mann-Whitney } \\
\text { U test }\end{array}$ & 0.151 \\
\hline Number of queens per colony & $\begin{array}{l}\text { Mann-Whitney } \\
\text { U test }\end{array}$ & 0.341 \\
\hline Number of nests per colony & $\begin{array}{l}\text { Mann-Whitney } \\
\text { U test }\end{array}$ & 1.000 \\
\hline Main food resources & Chi-squared test & 0.005 \\
\hline Daily activity rhythm & Chi-squared test & 0.003 \\
\hline Month of maximum activity & Chi-squared test & 0.300 \\
\hline $\begin{array}{l}\text { Critical thermal maximum } \\
\text { (CTM) }\end{array}$ & $\begin{array}{l}\text { Mann-Whitney } \\
\text { U test }\end{array}$ & 0.103 \\
\hline $\begin{array}{l}\text { Maximal activity temperature } \\
\text { (MAT) }\end{array}$ & $\begin{array}{l}\text { Mann-Whitney } \\
\text { U test }\end{array}$ & 0.018 \\
\hline Difference CTM-MAT & $\begin{array}{l}\text { Mann-Whitney } \\
\text { U test }\end{array}$ & 0.013 \\
\hline
\end{tabular}

Values significant at $\mathrm{p} \backslash 0.05$ are shown in bold species), while dominants were both scavenger, granivorous and aphid-tending species. With regard to activity rhythms, dominants and subordinates did not differ seasonally, but they did differ in their daily patterns. Dominants were generally active during the day-time in early spring and autumn, but nocturnal from late spring to late summer, while subordinates were active mainly during the day-time in all seasons (65\% of species), although others also changed from diurnal in spring to nocturnal in summer. Related to this diurnal activity, subordinates had higher MAT $\left(25.0 \pm 6.0\right.$ and $34.1 \pm 10.0{ }^{\circ} \mathrm{C}$ for dominant and subordinate species, respectively) and the difference between MAT and the critical physiological thermal maximum $(\mathrm{CTM})$ was also significant $(17.8 \pm 4.7$ and $11.2 \pm 6.4{ }^{\circ} \mathrm{C}$ for dominant and subordinate species, respectively) (Table 2 ).

Establishment of different groups of dominant and subordinate species according to these life traits

The dendrogram obtained by hierarchical methods identified six groups of species (Fig. 1), although one group was composed of only one species, Pheidole pallidula, and was not considered in further analyses. Many dominant species were grouped in three different sets separated by the analysis (groups 1, 2 and 3 of Fig. 1, together with P. pallidula, which was between these groups). Most subordinate species of medium to large size were also clustered together in groups 4 and 5 (Fig. 1), where no dominants were included. The only group that included both dominant and subordinate species was group 3, where mediumto small-sized species were clustered together, even if they were dominants (group 3a) or subordinates (group 3b). A subordinate species, Myrmica sabuleti, was even ranked in group 3a with three dominant species of the genus Tetramorium.

The comparison of life traits for the species included in the groups of the dendrogram showed significant differences among groups. Thus, species included in the different groups significantly differed in the five quantitative variables: worker size (Kruskal-Wallis test, $\mathrm{H}=23.2$, $\mathrm{P}=0.0001)$; number of workers at baits $(\mathrm{H}=9.3$, $\mathrm{P}=0.0500) ; \quad \mathrm{CTM} \quad(\mathrm{H}=20.0, \quad \mathrm{P}=0.0005), \quad \mathrm{MAT}$ $(\mathrm{H}=20.7, \quad \mathrm{P}=0.0004)$, and CTM-MAT $(\mathrm{H}=21.0$, $\mathrm{P}=0.0004)$. Figure 2 summarises the mean values of each group for these variables. Worker length was largest for species of group 1, and lowest for those of groups 2 and 3 (Fig. 2a). The number of workers per bait was largest for species of group 2 and 3a (Fig. 2b). The maximum values of CTM and MAT were those of group 4 (Fig. 2c, d). Finally, the difference between CTM and MAT was considerably lower for group 4 than for the other groups. The different groups also differed significantly in the six ordinal 
Fig. 1 Dendrogram of species similarities derived from UPGMA cluster analysis, based on life traits of each ant species. Dominance groups (dom): (?) dominant, (-) subordinate ant species

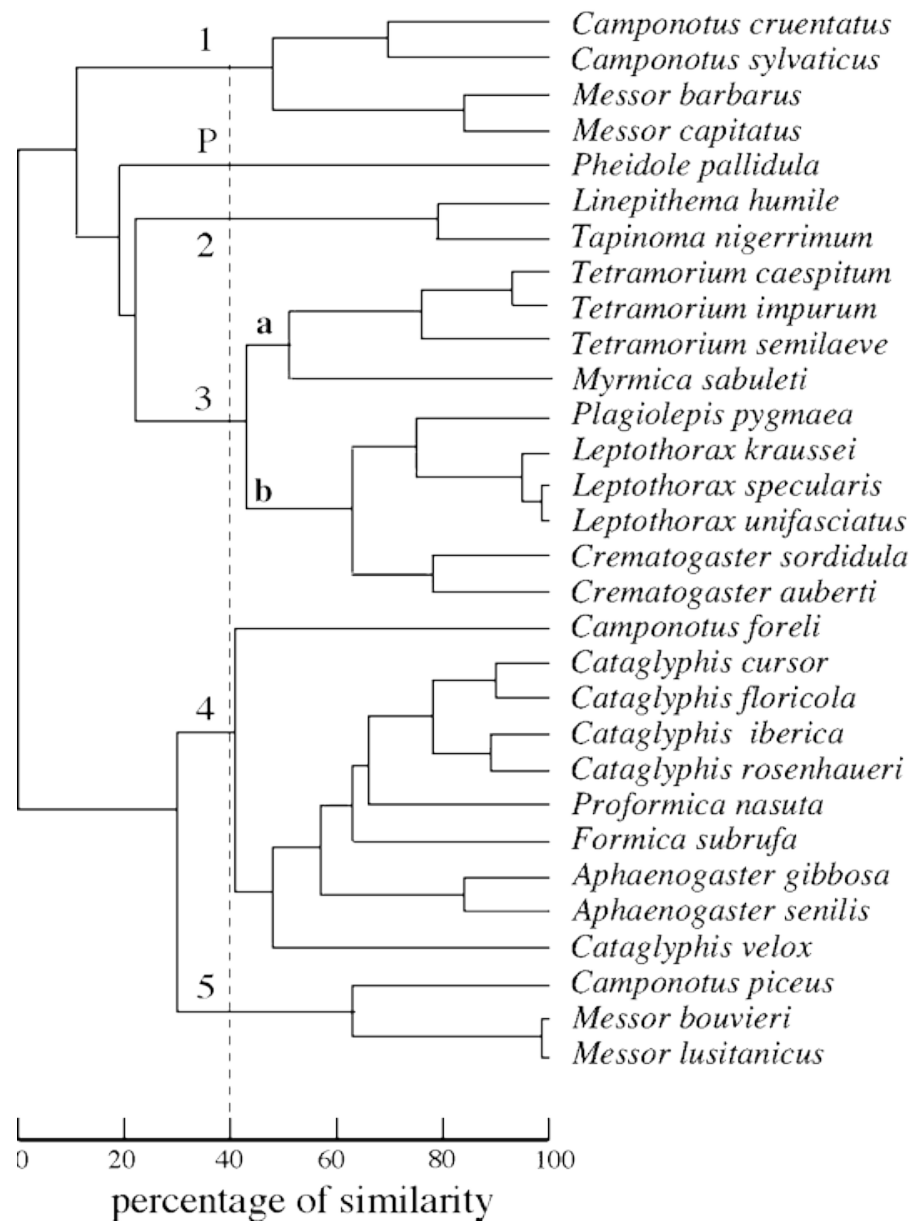

subfamily dom

Formicinae +

Formicinae +

Myrmicinae $\quad+$

Myrmicinae +

Myrmicinae +

Dolichoderinae +

Dolichoderinae +

Myrmicinae +

Myrmicinae +

Myrmicinae +

Myrmicinae -

Formicinae -

Myrmicinae -

Myrmicinae -

Myrmicinae -

Myrmicinae -

Myrmicinae -

Formicinae -

Formicinae -

Formicinae -

Formicinae -

Formicinae -

Formicinae -

Formicinae -

Myrmicinae -

Myrmicinae -

Formicinae -

Formicinae -

Formicinae -

Formicinae - variables. Species of group 1 had the highest degree of polymorphism, followed by the species of groups 5, 4 and 2 (Kruskal-Wallis test, $\mathrm{H}=17.4, \mathrm{P}=0.0037$ ). Species of groups 1, 2, 3a and 5 (and especially the two species of group 2) had more populated colonies than those of groups $3 \mathrm{~b}$ and $4(\mathrm{H}=20.7, \mathrm{P}=0.0009)$. Concerning colony composition, group 2 was only composed of two polygynous and polydomous species, while the other groups were mainly composed of monogynous and monodomous species (excepting the most specious group 4, with several species having more than one queen per colony) (number of queens per colony, $\mathrm{H}=11.9, \mathrm{P}=0.0359$; number of nests per colony, $\mathrm{H}=13.9, \mathrm{P}=0.0164)$. As regards the brood cycle, most groups were composed of species with larvae within the nest all the year, except group 4, which included many species with larvae within the nests only in the foraging activity season $(\mathrm{H}=16.9, \mathrm{P}=0.0046)$. The pattern observed with regard to the defence of resources was the same as in the previous analysis between dominant and subordinates, so that most subordinate species (of groups 3b, 4 and 5) only defend their nests, while the dominant species (groups 1, 2 and 3a) also defend the foraging area $(\mathrm{H}=19.3, \mathrm{P}=0.0017)$.

The Mantel analysis revealed that phylogenetic similarity had a highly significant positive effect on similarity of life traits (Mantel standardised statistic $r=0.45$, $\mathrm{P} \backslash 0.0001)$.

Distribution patterns of the different groups of species along environmental gradients

The first two axes of the CCA explained $79.8 \%$ of the variance in the groups of species-environment relationship. The first axis was mostly related to an aridity gradient, with positive values associated with annual total precipitation, but also to tree cover. The second axis could be seen as a thermal gradient, with positive values associated with annual mean temperature and negative values related to understory cover (Fig. 3). Dominant species of group 3a were strongly associated with sites with high temperatures; the same pattern, although not so accentuated, was observed with the subordinate species of groups 4 and 5 . 

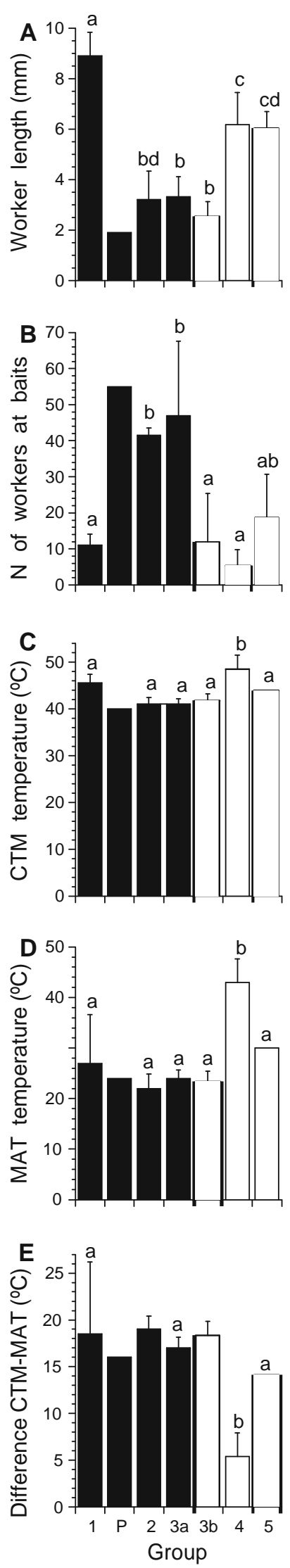

b Fig. 2 Mean (SD) values of a worker size (length, in mm); b number of workers at baits; c critical thermal maximum (CTM, in ${ }^{\circ} \mathrm{C}$ ); $\mathrm{d}$ maximum activity temperature (MAT, in ${ }^{\circ} \mathrm{C}$ ); and e difference between CTM and MAT (CTM-MAT) of the seven groups of species identified in the dendrogram of Fig. 1. Different letters indicate statistically significant differences between groups (Tukey's post-hoc test, $\mathrm{P} \backslash 0.05)$. The group $\mathrm{P}$ consisting only of P. pallidula has not been considered in the analyses. Black and white bars indicate dominant and subordinate subgroups, respectively

None of these species groups was conditioned by the aridity gradient. Cryptic species of group $3 \mathrm{~b}$ were associated with wet sites with high tree cover. Dominant species of group 2 were associated with relatively moist areas with a considerable tree and understory cover. The polymorphic dominant species of group 1 were associated with less hot or humid sites with a significant understory cover, whereas P. pallidula was mainly related to dry areas with low tree cover.

\section{Discussion}

In this study, we have been able to identify a set of ecologically relevant life traits of the most common Iberian ant species. More interestingly, we have firstly identified clearly distinctive life traits of dominant and subordinate species in Mediterranean environments. Thus, when compared with subordinates, dominants have some common traits that can be grouped under two main headings: resource exploitation and temporal activity patterns. On the one hand, dominant species have more populated colonies and defend food resources (that are mainly rich and stable ones, such as honeydew-producing groups of aphids;

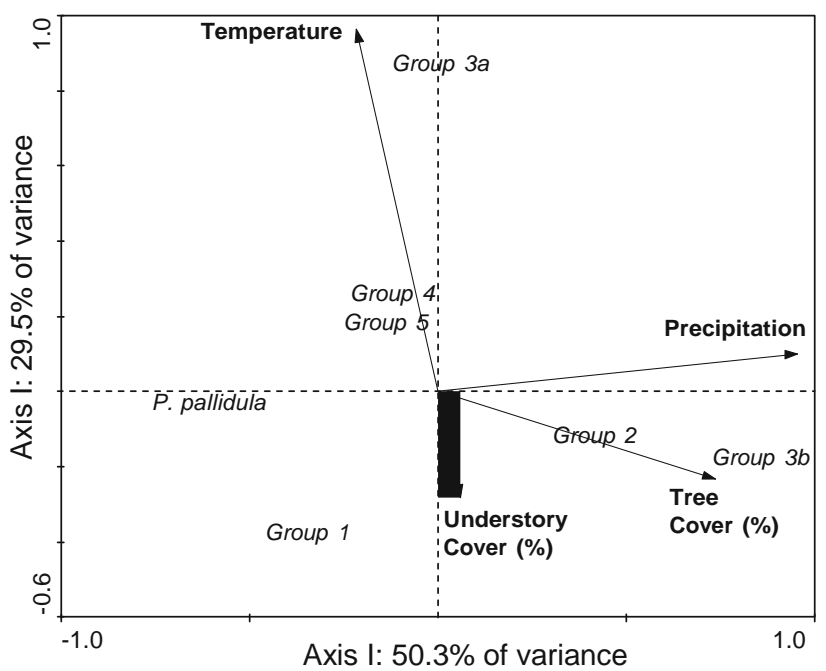

Fig. 3 Representation of the five groups (plus Pheidole pallidula) of ant species (in italics) and environmental factors (in bold) on the first two axes of the canonical correspondence analysis (CCA) 
Blüthgen et al. 2004; Pekas et al. 2011) more fiercely than subordinates (Table 2). The ecological advantages of large colony size in social insects include increased defence, homeostasis and work ability and greater ability to manipulate the surrounding environment (Bourke 1999). Moreover, dominant species in the Mediterranean region have better fighting abilities (Retana and Cerdá 1995) and recruit large numbers of workers to concentrated food resources (Cerdá et al. 1997, 1998c), which would explain their higher number of workers at baits in relation to subordinates (Table 2). On the other hand, dominant and subordinate species also differed in their daily foraging activity rhythms classifications, because dominants did not forage at high temperatures, whereas, in general, subordinates showed completely different patterns. These results confirm those of previous studies on ant communities in Mediterranean grasslands (Cros et al. 1997; Cerdá et al. 1998a), now extended to different habitat types across the Iberian Peninsula. As far as we know, this is the first attempt to identify the different levels within the competitive hierarchy (i.e. dominants and subordinates) from a large set of life traits in animals, and particularly in social insects.

In addition to the large differences found in life traits between dominants and subordinates in the Mediterranean region, we have also identified important differences among the species included within each of these two groups (Figs. 1, 2). Although there are no objective standardised techniques to compare functional group structures (Silva and Brandao 2010), our classification presents some similarities with the Andersen's functional groups of ants established in other parts of the world (Andersen 1995, 1997) (Table 3). The Andersen scheme classifies ants according to biogeographical scale responses to environmental stress and disturbance, but in turn most of

Table 3 Comparative table of our classification of ant groups and that of Andersen's $(1995,1997)$ ant functional groups classification in relation to stress and disturbance

\begin{tabular}{ll}
\hline Andersen's functional groups & Our ant groups classification \\
\hline Dominant Dolichoderinae & Group 2 \\
Subordinate Camponotini & Group 1 (?) \\
Hot climate specialists & Group 4 \\
Cold climate specialists & - \\
Tropical climate specialists & - \\
Cryptic species & Group 3b \\
Opportunists & - \\
Generalised Myrmicinae & Group 3a ? P. pallidula \\
& Group 1 (?) \\
Specialist predators & - \\
- & Group 5 \\
\hline
\end{tabular}

the functional groups can be placed into different levels of the dominance hierarchy (Arnan et al. 2011). The first major similarity is that, according to our phylogenetic contrasts, the species that compose the different assemblages are, as a rule, phylogenetically closer than the species of different groups. Group 2 of dominant ants includes two Dolichoderine species of relatively small size and large-populated colonies: a Mediterranean species, Tapinoma nigerrimum, and an invasive species, the Argentine ant (Linepithema humile). The latter is an increasingly important global invader, particularly in Mediterraneantype ecosystems (Holway 1998; Giraud et al. 2002). Both species share many life traits: they have high numbers of workers at baits compared to other dominant groups (Fig. 2), and they are also the only polygynous and polydomous dominant species, which confers on them a great competitive advantage in relation to other dominant species (McGlynn 1999). In other areas of the world, dominant ants are strongly territorial ants, such as those species of the dominant Dolichoderinae functional group of the Andersen's scheme (Andersen 1992, 1995, 1997). Although with a lower degree of aggressiveness and territoriality, L. humile and $\mathrm{T}$. nigerrimum would be the only species that would have more resemblance to this functional group (Table 3). The subdominant species of the classification of Vepsäläinen and Pisarski (1982) in boreal biomes and of Arnan et al. (2011) in sub-tropical biomes are non-territorial but aggressive when defending or trying to take over concentrated food resources. These species are capable of achieving moderate densities in areas where the dominants are absent or in lacunae in the mosaic of dominants (Savolainen et al. 1989; Arnan et al. 2011). In our study, this role is accomplished by dominant species of groups 1 and 3a, which can dominate food resources but do not defend territories surrounding their nests. Group 1 includes polymorphic, dominant ants (Camponotus spp. and Messor spp.) with larger workers (Fig. 1) mainly concerned with tasks of defending nest and food (Hölldobler and Wilson 1990). Meanwhile, group 3a is mainly composed of small dominant species belonging to the genus Tetramorium. Myrmica sabuleti was placed together with them because they have several features in common, although the criteria followed did not allow us to classify it as a dominant species. Both phylogenetically and for their role in the dominance hierarchy (Arnan et al. 2011), these two groups could be perfectly paralleled to the generalised Myrmicinae of Andersen's classification (Table 3), with the exception of the two Camponotus species of Group 1, which could be included within the Subordinate Camponotini group. In Australia, species of Camponotus can also be highly competitive at baits (Andersen 1992), especially in the absence of Iridomyrmex (Andersen and Patel 1994). Similar species to those of these two groups are also 
considered as dominant species in other biomes, like a South African savanna (Parr 2008) and a sub-tropical area of New Zealand (Stringer et al. 2007), where territorial dominant species are absent.

The subordinate species from our study areas were also included in completely different groups. There is, additionally, an important phylogenetic effect on this clustering (Fig. 1). On the one hand, species of group $3 \mathrm{~b}$ in the dendrogram (Fig. 1) are small and monomorphic, heatintolerant species, which were clustered with dominant species of the genus Tetramorium, due to their small size, nocturnal habits and low heat tolerance (Fig. 2). The ant species included in group 3b can cope with the stresses and variation of the Mediterranean climate by evading extreme conditions through adjustments in behavioural or ecological features of life histories, and are similar to cryptic species described for Australian and North American ant faunas (Andersen 1995, 1997). The other subordinates were clustered in two different groups. Group 4 is composed of species that they are mainly able to withstand hot or very hot thermal environmental conditions (Cerdá et al. 1989; Cerdá and Retana 1997a, b), similar to taxa recognised as hot climate specialists in Africa, Australia, and North America (Marsh 1985; Andersen 1997). In the Mediterranean areas, these species have achieved morphological (such as large worker polymorphism; Cerdá and Retana 1997a), physiological (such as low cuticular transpiration) and behavioural (such as raising their abdomen to protect the vital organs contained in it from high temperatures) adaptations to tolerate thermal stress (Cerdá and Retana 2000). This group of species also differs from the other subordinates because most of the species have larvae in the nests only in the foraging activity season, in contrast to the other groups of species which have larvae in the nests throughout the year; moreover, several species are polygynous and polydomous. This set of life traits (larvae throughout the year, polygynous and polydomous) could be seen as a typical syndrome of those Mediterranean ant species with thermal stress tolerance, but further research is needed to test how prevalent it is along other species not sampled here. The last group of subordinates (group 5 in Fig. 1) includes species with similar worker size to hotclimate specialists, but showing important differences (Fig. 2). Thus, they tolerate and forage at lower temperatures beyond their critical limits (Cerdá et al. 1998b). This group does not have any resemblance to any of the Andersen's functional groups (Table 3).

As discussed so far, particular life traits of the different ant functional groups allow them to preferentially inhabit areas with specific environmental conditions. Consequently, as in other areas of the world (Andersen 1995, 1997), functional group composition in the Mediterranean areas of this study varied along the environmental gradients
(Fig. 3). There is a shift from dominant Dolichoderinae and cryptic species in moist areas, with considerable tree and understory cover, to dominant Myrmicinae and hot climate specialists mainly in open and hot sites. Another dominant species, Pheidole pallidula, and polymorphic species from the genera Messor and Camponotus were associated with intermediate sites. This model proves to be only descriptive because we were not able to test its predictability with other databases of the same region, something that should be validated in future work. In any case, this pattern is in accordance with the particular life traits of each group of species that allow them to withstand the specific conditions of each site. Life traits of species can facilitate the exploitation and dominance of food resources or buffer them against adverse conditions of the physical environment, i.e. contributing to structure the communities where they live (Chesson and Huntly 1988; Silva and Brandao 2010). However, these results contrast with those of other biogeographic regions such as Australia and North America, where dominant Dolichoderinae and generalised Myrmicinae (e.g. Pheidole spp.) dominate in hot and open habitats, but they match in that cryptic species are more abundant in forested and moist habitats (Andersen 1997). This suggests that, although some of our groups of ants paralleled to those of Andersen's functional groups classification, some important and prevailing life traits within each group must differ considerably. An explanation here relies on the fact that our classification is based on a set of measurable traits, rather than simply relying on taxonomic grouping and/or non-comparable qualitative behaviour information (Silva and Brandao 2010).

In spite of many differences existing among the Mediterranean habitats considered along the environmental gradients, some common life traits within the groups of both dominants and subordinates always emerge from the assemblies of ant species, and they do not only depend on phylogenetic similarities. However, other life traits make within-groups differentiation, which suggests that specific life traits also allow coping with particular environmental conditions. There is thus an urgent need for further research on how functional traits at community level vary along environmental gradients, rather than focusing on specific identity variations (McGill et al. 2006), which in turn may allow us to predict community assembly rules in different ecological scenarios.

Acknowledgments This study was partly funded by the Spanish “Ministerio de Ciencia e Innovación” (project Consolider MONTES, CSD 2008-00040 to J.R. and project CGL2009-09690/BOS to X.C.). We are grateful to Rocío Requerey, Alicia Prieto and Olga Guerrero for bibliographic assistance, to Elena Angulo for help with the (sometimes unfruitful) statistics, to Alain Lenoir and Raphaël Boulay for very helpful comments during coffee (or beer) breaks. Thanks are also due to our colleagues and friends Anna Alsina, Jordi Bosch, Raphaël Boulay, Valentín Cavia, Soledad Carpintero, Sebastià Cros, Xavier Espadaler, Paqui Ruano and Alberto Tinaut, for providing us 
with data about the ant traits. All experiments comply with current Spanish laws.

\section{References}

Andersen AN (1992) Regulation of "momentary" diversity by dominant species in exceptionally rich ant communities of the Australian seasonal tropics. Am Nat 140:401-420

Andersen AN (1995) A classification of Australian ant communities, based on functional groups which parallel plant life-forms in relation to stress and disturbance. J Biogeogr 22:15-29

Andersen AN (1997) Functional groups and patterns of organisation in North American ant communities: a comparison with Australia. J Biogeogr 24:433-460

Andersen AN, Patel AD (1994) Meat ants as dominant members of Australian ant communities: an experimental test of their influence on the foraging success and forager abundance of other species. Oecologia 98:15-24

Arnan X, Rodrigo A, Retana J (2006) Post-fire recovery of Mediterranean ground ant communities follows vegetation and dryness gradients. J Biogeogr 33:1246-1258

Arnan X, Rodrigo A, Retana J (2007) Uncoupling the effects of shade and food resources of vegetation on Mediterranean ants: an experimental approach at the community level. Ecography 30:161-172

Arnan X, Gaucherel C, Andersen AN (2011) Dominance and species co-occurrence in highly diverse ant communities: a test of the interstitial hypothesis and discovery of a three-tiered competition cascade. Oecologia 166:783-794. doi:10.1007/s00442-0111919-y

Baroni-Urbani C, Bolton B, Ward P (1992) The internal phylogeny of ants (Hymenoptera: Formicidae). Syst Entomol 17:301-329

Bestelmeyer BT (2000) The trade-off between thermal tolerance and behavioural dominance in a subtropical South American ant community. J Anim Ecol 69:998-1009

Blüthgen N, Stork NE, Fiedler K (2004) Bottom-up control and cooccurrence in complex communities: honeydew and nectar determine a rainforest ant mosaic. Oikos 106:344-358

Bourke AFG (1999) Colony size, social complexity and reproductive conflict in social insects. J Evol Biol 12:245-257

Cerdá X, Retana J (1997a) Links between worker polymorphism and thermal biology in a thermophilic ant species. Oikos 78:467-474

Cerdá X, Retana J (1997b) Interference interactions and nest usurpation between two subordinate ant species. Oecologia 113:577-583

Cerdá X, Retana J (2000) Alternative strategies by thermophilic ants to cope with extreme heat: individual versus colony level traits. Oikos 89:155-163

Cerdá X, Retana J, Bosch J, Alsina A (1989) Daily foraging activity and food collection of the thermophilic ant Cataglyphis cursor (Hymenoptera, Formicidae). Vie Milieu 39:207-212

Cerdá X, Alsina A, Retana J (1990) Coexistencia de tres especies simpátridas del género Camponotus Mayr (Hymenoptera, Formicidae). In: Arias de Reyna L, Recuerda P, Redondo T (eds) Principios en etología. Publ Monte de Piedad y Caja de Ahorros de Córdoba, Córdoba, pp 117-130

Cerdá X, Retana J, Cros S (1997) Thermal disruption of transitive hierarchies in Mediterranean ant communities. J Anim Ecol 66:363-374

Cerdá X, Retana J, Manzaneda A (1998a) The role of competition by dominants and temperature in the foraging of subordinate species in Mediterranean ant communities. Oecologia 117:404-412

Cerdá X, Retana J, Cros S (1998b) Critical thermal limits in Mediterranean ant species: trade-off betwen mortality risk and foraging performance. Funct Ecol 12:45-55
Cerdá X, Retana J, Cros S (1998c) Prey size reverses the outcome of interference interactions of scavenger ants. Oikos 82:99-110

Chesson P, Huntly N (1988) Community consequences of life-history traits in a variable environment. Ann Zool Fenn 25:5-16

Colwell RK, Futuyma DJ (1971) On the measurements of niche breadth and overlap. Ecology 52:567-576

Cros S, Cerdá X, Retana J (1997) Spatial and temporal variations in the activity patterns of Mediterranean ant communities. Ecoscience 4:269-278

Deslippe RJ, Savolainen R (1995) Mechanisms of competition in a guild of formicine ants. Oikos 72:67-73

Fellers JH (1987) Interference and exploitation in a guild of woodland ants. Ecology 68:1466-1478

Futuyma DJ, Moreno G (1988) The evolution of ecological specialization. Annu Rev Ecol Syst 19:207-233

Gibb H, Hochuli DF (2004) Removal experiment reveals limited effects of a behaviorally dominant species on ant assemblages. Ecology 85:648-657

Giraud T, Pedersen JS, Keller L (2002) Evolution of supercolonies: the Argentine ants of southern Europe. Proc Natl Acad Sci USA 99:6075-6079

Hölldobler B, Wilson EO (1990) The ants. Springer, Berlin

Holway DA (1998) Effect of Argentine ant invasions on grounddwelling arthropods in northern California riparian woodlands. Oecologia 116:252-258

Human KG, Gordon DM (1996) Exploitation and interference competition between the invasive Argentine ant, Linepithema humile, and native ant species. Oecologia 105:405-412

Human KG, Weiss S, Sandler B, Gordon DM (1998) Effects of abiotic factors on the distribution and activity of the invasive Argentine ant (Hymenoptera: Formicidae). Environ Entomol 27:822-833

Lach L, Parr CL, Abbott KL (2010) Ant ecology. Oxford University Press, Oxford

Legendre P, Vaudor A (1991) The R package: multidimensional analysis, spatial analysis. Departement de sciences biologiques, Université de Montreal, Quebec

Marsh AC (1985) Microclimatic factors influencing foraging patterns and success of the thermophilic desert ant, Ocymyrmex barbiger. Insect Soc 32:286-296

McGill BJ, Enquist BJ, Weither E, Westoby M (2006) Rebuilding community ecology from functional traits. Trends Ecol Evol 21:178-185

McGlynn TP (1999) The worldwide transport of ants: geographic distribution and ecological invasions. J Biogeogr 26:535-548

Melville J, Harmon LJ, Losos JB (2006) Intercontinental community convergence of ecology and morphology in desert lizards. Proc R Soc Lond B 273:557-563

Ninyerola M, Pons X, Roure JM (2005) Atlas Climático Digital de la Península Ibérica. Metodología y aplicaciones en bioclimatología y geobotánica. ISBN 932860-8-7. Universidad Autónoma de Barcelona, Bellaterra

Orshan G (1983) Approaches to the definition on Mediterranean growth forms. In: Kruger FJ, Mitchell DT, Jarvis JUM (eds) Mediterranean-type ecosystems. The role of nutrients. Springer, Berlin, pp 86-100

Parr CL (2008) Dominant ants can control assemblages species richness in a South African savanna. J Anim Ecol 33:830-838

Pekas A, Tena A, Aguilar A, García-Marí F (2011) Spatio-temporal patterns and interactions with honeydew-producing Hemiptera of ants in a Mediterranean citrus orchard. Agric For Entomol 13:89-97

Pisarski B, Vepsäläinen K (1989) Competition hierarchies in ant communities (Hymenoptera, Formicidae). Ann Zool 42:321-329

Purvis A, Gittleman JL, Luh HK (1994) Truth or consequences: effects of phylogenetic accuracy on two comparative methods. J Theor Biol 167:293-300 
Putman RJ (1994) Community ecology. Chapman \& Hall, London

Retana J, Cerdá X (1995) Agonistic relationships among sympatric Mediterranean ant species (Hymenoptera: Formicidae). J Insect Behav 8:365-380

Retana J, Cerdá X (2000) Patterns of diversity and composition of Mediterranean ant communities tracking spatial and temporal variability of the thermal environment. Oecologia 123:436-444

Savolainen R, Vepsäläinen K (1988) A competition hierarchy among boreal ants: impact on resource partitioning and community structure. Oikos 51:135-155

Savolainen R, Vepsäläinen K, Wuorenrinne H (1989) Ant assemblages in the taiga biome: testing the role of territorial wood ants. Oecologia 81:481-486

Sevenster JG, Van Alphen JM (1993) A life history trade-off in Drosophila species and community structure in variable environments. J Anim Ecol 62:720-736

Silva RR, Brandao CRF (2010) Morphological patterns and community organisation in leaf-litter ant assemblages. Ecol Monogr 80:107-124
StatSoft (2001) STATISTICA, version 6. www.statsoft.com

Stringer LD, Haywood J, Lester PJ (2007) The influence of temperature and fine-scale resource distribution on resource sharing and domination in an ant community. Ecol Entomol 32:732-740

ter Braak CJF, Smilauer P (1998) CANOCO reference manual and user's guide to canoco for windows: software for canonical community ordination (Version 4). MicrocomputerPower, Ithaca

Thygesen UH, Farnsworth KD, Andersen KH, Beyer JE (2005) How optimal life history changes with the community size-spectrum. Proc R Soc Lond B 272:1323-1331

Vepsäläinen K, Pisarski B (1982) Assembly of island ant communities. Ann Zool Fenn 19:327-335

Wiens JA, Addicott JF, Case TJ, Diamond J (1986) Overview: the importance of spatial and temporal scale in ecological investigations. In: Diamond J, Case TJ (eds) Community ecology. Harper \& Row, New York, pp 145-153 
Table S1. Life traits of ant species considered in this study. Information was derived from personal observations, from the literature, and from personal communications from various colleagues. Polymorphism: 1 , monomorphism; 2 , low polymorphism; 3 , high polymorphism. Colony population: 1 , hundreds; 2 , thousands; 3 , tens of thousands. Brood cycle: 1 , larvae in the nests from March to September; 2 , larvae in the nests during the whole year. Defence of resources: 1, none; 2, food and/or territory. Daily activity rhythms: D, diurnal; DC, diurnal in spring and continuous or with a midday drop in summer; CN, continuous in spring and nocturnal in summer; $\mathrm{N}$, nocturnal. CTM, critical thermal maximum (in ${ }^{\circ} \mathrm{C}$ ). MAT, maximum activity temperature (in ${ }^{\circ} \mathrm{C}$ ). ${ }^{*}$ : majo workers; **: minor workers.

\begin{tabular}{|c|c|c|c|c|c|c|c|}
\hline Species & $\begin{array}{l}\text { Mean Worker } \\
\text { length }(\mathrm{mm})\end{array}$ & Polymorphism & $\begin{array}{l}\text { Colony } \\
\text { population }\end{array}$ & $\begin{array}{l}\text { Brood } \\
\text { cycle }\end{array}$ & $\begin{array}{l}\mathrm{N} \text { queens per } \\
\text { colony }\end{array}$ & $\begin{array}{l}\mathrm{N} \text { nests per } \\
\text { colony }\end{array}$ & $\begin{array}{l}\text { Main food } \\
\text { resource }\end{array}$ \\
\hline Linepithema humile & 2.4 & 1 & 3 & 2 & polygyny & polydomy & honeydew \\
\hline Tapinoma nigerimum & 4.0 & 2 & 3 & 2 & polygyny & polydomy & honeydew \\
\hline Camponotus cruentatus & 10.0 & 3 & 2 & 2 & monogyny & monodomy & honeydew \\
\hline Camponotus foreli & 7.0 & 3 & 1 & 2 & monogyny & polydomy & nectar \\
\hline Camponotus piceus & 5.2 & 2 & 1 & 2 & monogyny & monodomy & nectar \\
\hline Camponotus sylvaticus & 9.3 & 3 & 2 & 2 & monogyny & monodomy & honeydew \\
\hline Cataqlyphis cursor & 5.8 & 2 & 1 & 1 & monogyny & monodomy & insects \\
\hline Cataglyphis floricola & 6.0 & 1 & 1 & 1 & monogyny & monodomy & insects \\
\hline Cataglyphis iberica & 7.6 & 3 & 1 & 1 & monogyny & polydomy & insects \\
\hline Cataglyphis rosenhaueri & 5.7 & 2 & 1 & 1 & monogyny & polydomy & insects \\
\hline Cataglyphis velox & 8.3 & 3 & 1 & 1 & polygyny & polydomy & insects \\
\hline Formica subrufa & 4.9 & 1 & 1 & 1 & monogyny & monodomy & insects \\
\hline Plagiolepis pygmaea & 1.6 & 1 & 1 & 2 & polygyny & monodomy & nectar \\
\hline Proformica nasuta & 4.5 & 3 & 1 & 1 & monogyny & monodomy & insects \\
\hline Aphaenogaster gibbosa & 4.9 & 1 & 1 & 2 & monogyny & monodomy & insects \\
\hline Aphaenogaster senilis & 7.1 & 1 & 1 & 2 & monogyny & monodomy & insects \\
\hline Crematogaster auberti & 3.4 & 1 & 2 & 2 & monogyny & monodomy & nectar \\
\hline Crematogaster sordidula & 2.5 & 1 & 1 & 2 & monogyny & monodomy & nectar \\
\hline Leptothorax kraussei & 2.8 & 1 & 1 & 2 & monogyny & monodomy & nectar \\
\hline Leptothorax specularis & 2.5 & 1 & 1 & 2 & monogyny & monodomy & nectar \\
\hline Leptothorax unifasciatus & 2.5 & 1 & 1 & 2 & monogyny & monodomy & nectar \\
\hline Messor barbarus & 7.9 & 3 & 2 & 2 & monogyny & monodomy & seeds \\
\hline Messor bouvieri & 6.3 & 2 & 2 & 2 & monogyny & monodomy & seeds \\
\hline Messor capitatus & 8.4 & 3 & 2 & 2 & monogyny & monodomy & seeds \\
\hline Messor lusitanicus & 6.5 & 2 & 2 & 2 & monogyny & monodomy & seeds \\
\hline Myrmica sabuleti & 4.4 & 1 & 1 & 2 & polygyny & monodomy & insects \\
\hline Pheidole pallidula & $1.9^{\star} / 4.1^{\star *}$ & 3 & 3 & 1 & monogyny & monodomy & insects \\
\hline Tetramorium caespitum & 2.9 & 1 & 2 & 2 & monogyny & monodomy & insects \\
\hline Tetramorium impurum & 3.4 & 1 & 2 & 2 & monogyny & monodomy & insects \\
\hline Tetramorium semilaeve & 2.6 & 1 & 2 & 2 & polyayny & monodomy & insects \\
\hline
\end{tabular}


Online resource. Continuation

\begin{tabular}{|c|c|c|c|c|c|c|c|}
\hline Species & $\begin{array}{l}\text { Defense of } \\
\text { resources }\end{array}$ & $\begin{array}{l}\text { Mean Number } \\
\text { workers/bait }\end{array}$ & $\begin{array}{l}\text { Daily } \\
\text { rhythm }\end{array}$ & $\begin{array}{l}\text { Month of peak } \\
\text { activity }\end{array}$ & CTM $\left({ }^{\circ} \mathrm{C}\right)$ & MAT $\left({ }^{\circ} \mathrm{C}\right)$ & $\begin{array}{l}\text { Phylogeny } \\
\text { code }\end{array}$ \\
\hline Linepithema humile & 2 & 40 & $\mathrm{CN}$ & September & 40 & 20 & BBB \\
\hline Tapinoma nigerimum & 2 & 43 & $\mathrm{CN}$ & June & 42 & 24 & BBA \\
\hline Camponotus cruentatus & 2 & 8 & DC & July & 48 & 40 & BAAAAB \\
\hline Camponotus foreli & 1 & 6 & $\mathrm{D}$ & August & 48 & 44 & BAAAAAA \\
\hline Camponotus piceus & 1 & 4 & $\mathrm{D}$ & July & 44 & 30 & BAAAB \\
\hline Camponotus sylvaticus & 2 & 9 & $\mathrm{~N}$ & August & 46 & 28 & BAAAAAB \\
\hline Cataglyphis cursor & 1 & 3 & D & July & 50 & 48 & BAABBBAA \\
\hline Cataglyphis floricola & 1 & 2 & $\mathrm{D}$ & July & 50 & 44 & BAABBBAB \\
\hline Cataglyphis iberica & 1 & 3 & D & July & 52 & 50 & BAABBBBAA \\
\hline Cataglyphis rosenhaueri & 1 & 1 & $\mathrm{D}$ & July & 50 & 44 & BAABBBBAB \\
\hline Cataglyphis velox & 1 & 2 & $\mathrm{D}$ & July & 52 & 46 & BAABBBBB \\
\hline Formica subrufa & 2 & 7 & $\mathrm{D}$ & July & 48 & 40 & BAABA \\
\hline Plagiolepis pygmaea & 1 & 9 & $\mathrm{CN}$ & May & 40 & 22 & $\mathrm{BAB}$ \\
\hline Proformica nasuta & 1 & 3 & $\mathrm{D}$ & June & 46 & 36 & BAABBA \\
\hline Aphaenogaster gibbosa & 1 & 15 & $\mathrm{D}$ & July & 42 & 36 & ABABBB \\
\hline Aphaenogaster senilis & 1 & 11 & $\mathrm{D}$ & June & 46 & 42 & ABABBA \\
\hline Crematogaster auberti & 2 & 33 & $\mathrm{CN}$ & July & 44 & 24 & ABBBA \\
\hline Crematogaster sordidula & 2 & 24 & $\mathrm{CN}$ & May & 40 & 20 & ABBBB \\
\hline Leptothorax kraussei & 1 & 2 & $\mathrm{CN}$ & June & 42 & 26 & ABBAC \\
\hline Leptothorax specularis & 1 & 2 & $\mathrm{CN}$ & June & 42 & 24 & ABBAA \\
\hline Leptothorax unifasciatus & 1 & 2 & $\mathrm{CN}$ & June & 42 & 24 & ABBAB \\
\hline Messor barbarus & 2 & 12 & DC & September & 44 & 18 & ABABAAB \\
\hline Messor bouvieri & 1 & 26 & $\mathrm{D}$ & September & 44 & 30 & ABABABA \\
\hline Messor capitatus & 2 & 15 & $\mathrm{DC}$ & October & 44 & 22 & ABABAAA \\
\hline Messor lusitanicus & 1 & 25 & D & September & 44 & 30 & ABABABB \\
\hline Myrmica sabuleti & 2 & 17 & $\mathrm{~N}$ & June & 40 & 22 & AA \\
\hline Pheidole pallidula & 2 & 55 & $\mathrm{CN}$ & September & 40 & 24 & ABAA \\
\hline Tetramorium caespitum & 2 & 50 & $\mathrm{CN}$ & July & 42 & 26 & $A B B C A B$ \\
\hline Tetramorium impurum & 2 & 60 & $\mathrm{CN}$ & July & 42 & 24 & ABBCB \\
\hline Tetramorium semilaeve & 2 & 61 & $\mathrm{CN}$ & June & 40 & 24 & ABBCAA \\
\hline
\end{tabular}

